\title{
MANAGEMENT OF IRRIGATION FARMS UNDER HIGH STOCKING
}

\author{
G. R. L. BROWN \\ $M$ inistry of A griculture and Fisheries, Oamaru
}

\begin{abstract}
High stocking rates on irrigated pastures are not unrealistic because seasonal pasture production is predictable. For best utilization this feed should be eaten in situ. Therefore stock policies with demand patterns that best follow the pasture production curve have an advantage. On the Lower Waitaki Plains, to which this paper pertains, the typical irrigation farm- will be $70 \%$ border-dyked. The remaining $30 \%$ of land can be a useful complement,
\end{abstract}

\section{INTRODUCTION}

HIGH STOCKING RATE is the number of stock required to fully utilize pasture growth. To achieve efficient utilization in an economic sense, the maximum amount of pasture should be eaten in situ.

Stock policies with feed demands that match pasture production under irrigation will be considered. These are breeding ewes and breeding cows.

The existing situation on the Lower Waitaki Plains will be considered in this paper.

\section{PASTURE PRODUCTION}

On the Lower Waitaki Plains, $10300 \mathrm{~kg}$ of dry matter per hectare annually ( $\mathrm{kg} \mathrm{DM} / \mathrm{ha} / \mathrm{yr})$ have been measured from irrigated pastures. The same conditions at Winchmore have averaged $10500 \mathrm{~kg} \mathrm{DM} / \mathrm{ha} / \mathrm{yr}$. With irrigated pastures yielding in this range, there is a potential for a carrying capacity of 20 stock units (s.u.) 'per hectare.

Reliable yields are a major advantage with irrigated pastures. A variable has been eliminated; therefore, high stocking rates can be carried with more assurance.

The production pattern from these pastures on the Lower Waitaki Plains is illustrated in Fig. 1 and highlights the tremendous difference between summer and winter production. The pastures are of 'Grasslands Ruanui' ryegrass (Lolium perenne) 


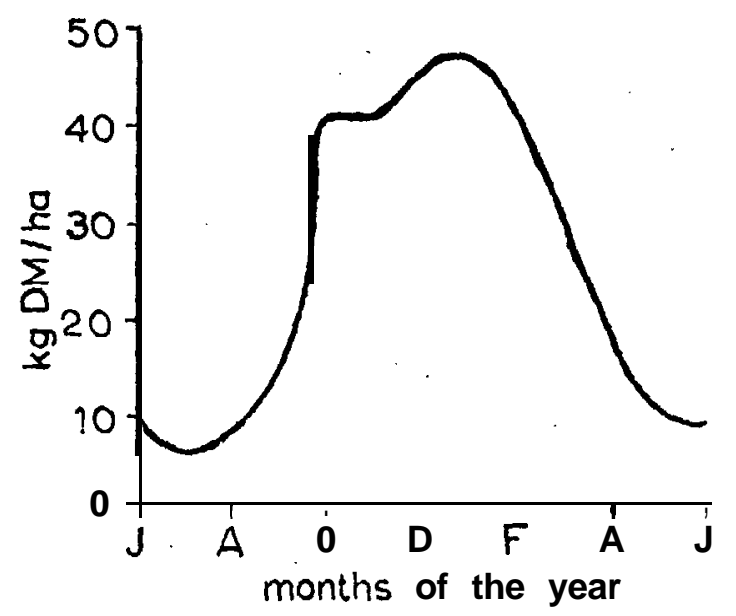

FIG. 1: Irrigated pasture production curve, Lower Waitaki.

This is taken from Winchmore data, except spring production has been delayed two weeks.

and 'Grasslands Huia' white clover (Trifolium repens) and about $40 \%$ of the pasture is weed grasses.

In summer, pastures are producing ten times more than in the winter. Problems arise when attempts are made to match stock demands to production. From a maintenance situation to lactation, breeding cows can increase their appetite $4 \frac{1}{2}$ times, ewes only 23 on these irrigated pastures. They cannot match the lo-fold increase in pasture production and this creates problems.

Because there are insufficient production data from the Waitaki Plains, records from Winchmore have been used with the exception that spring production is about two weeks later.

\section{BREEDING EWES}

The feed demand of ewes is best illustrated by a graph showing the demands at different stages of the year.

Figure 2 shows the ewes' feed demand at a stocking rate of $20 /$ ha.

When calculating demand, account has to be taken of the quality of feed being offered, the liveweight of the animal, and the physiological state of the ewe. 


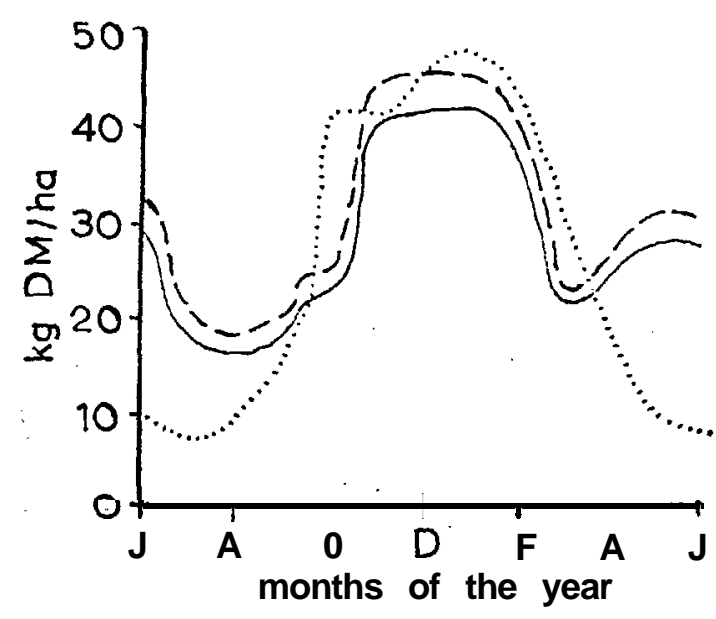

Fig. 2: Breeding 'ewe feed demand curve..

This shows the seasonal DM requirements of the ewe on pasture including lucerne hay in winter. The solid line is the demand of ewes at $20 /$ ha, the dashed line ewes at $22 / \mathrm{ha}$. Superimposed on this is a dotted line, representing the pasture production curve.

The higher the quality of the feed, the lower the intake level required. Also, a ewe in the winter requires only a fraction of the feed of a ewe with a lamb.

For further reference to these calculations, a modified table (Jagusch, 1973) of feed requirements as compiled by the Great Britain Agricultural Research Council has been used. Basically the modification entails increasing requirements by $30 \%$ for the grazing animal. (An example of a modified table is given in the appendix.)

When this demand pattern is matched with pasture production, it is evident that supply is just adequate to meet prelambing requirements. From then on a surplus of feed exists. Lambing is $120 \%$, and lambs are on the ewes until January when they are weaned and $50 \%$ drafted. Remaining lambs are grazed till the end of March.

In April the feed situation is falling rapidiy, but stock demand is increasing for flushing. Surplus feed can be carried over from spring and summer to this period.

Increased stocking rate, as illustrated in Fig. 2 reduces surpluses. 


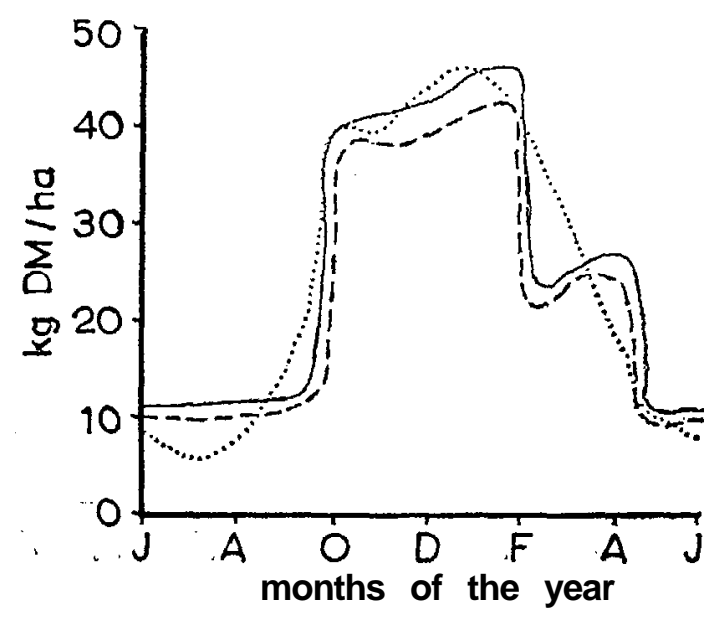

Fig. 3: Breeding cow feed demand curve.

This diagram represents the seasonal demand of cows at $2.7 /$ ha (solid line) and 2.5 cows /ha (dashed line). The dotted line is the pasture production curve.

\section{BREEDING COWS}

The feed demand pattern for cows at $2.7 /$ ha almost fits the pasture production curve.

Calving can coincide with spring growth, starting on September 1. This ensures a carryover of some feed to late October when demand exceeds supply. By weaning calves feed requirements can be reduced dramatically. As these weaners grow, however, feed requirements increase, as illustrated in Fig. 3. Some of the feed surpluses from February can be carried into late March and April. The effects of a lower stocking rate can be seen, the lower being depicted by the dashed line. Surpluses become evident. Stocked at 2.7 cows/ha, $400 \mathrm{~kg}$ cows should be maintained, and weaners sold in April at weights exeeding $200 \mathrm{~kg}$. Calving performance should be over $95 \%$.

Feed requirements for a breeding cow and calf were calculated from tables similar to those used for ewe demands. Because this cow is high performing it is equivalent to 7.4 s.u. Ewes could be fed over the spring/summer/autumn period, at a stocking rate of $22 /$ ha. It appears that cows would be struggling. The difference is that the cow demand is so much higher in summer than winter when compared with a ewe. However, the ultimate could be a nurse cow system at slightly lower stocking rates, 
TYPICAL FARM

On the Lower Waitaki Plains the typical farm will be on a stony soil type not suited to cropping. Seventy percent of its area is border-dyked, the remaining $30 \%$ being unsuitable because of its complex topography, This area could be spray-irrigated to provide hay for winter feed. Enough could be grown to enable stock carrying capacities, that will fully utilize pasture growth on border-dykes, in the growing season, to be wintered satisfactorily.

\section{GRAZING SYSTEMS}

Rotational grazing of stock is desirable with a high stocking rate. At any time the feed surplus in the system can be assessed far more simply than under set-stocking. In the writer's opinion this grazing also encourages pasture species which have a longer spread of seasonal growth, thereby reducing the summer peak relative to spring and autumn. By rationing stock in a rotation, feed can be manipulated and fed in periods when stock need more feed.

General results from pasture grazing research indicate that pastures should be short in winter, and allowed to get longer in the summer for better growth. In the stocking systems that follow these general principles have been attempted.

\section{Ewe Grazing System}

Over lambing, ewes can be set-stocked, then rotationally grazed from early November onwards. Pasture length increases from lambing onwards, the rotation commencing on pastures $60 \mathrm{~mm}$ high. In a four-paddock rotation,. one paddock will provide about three days' grazing till the height is reduced to $25 \mathrm{~mm}$. Towards the end of November, pastures get longer. Ewes and lambs rotationally grazing till weaning will only be grazing pastures to $50 \mathrm{~mm}$.

After weaning, lambs can be rotated around pastures about 150 $\mathrm{mm}$ in height. They can be given the pickings from these pastures. Ewes can, follow, cleaning up stalky and dried remains. Lambs will graze shorter, clovery pastures on the next rotation. Ewes over this period are fed maintenance diet only, this being checked by weighing a few marked ewes.

The majority of lambs should be drafted by March. After the ewes have bared off the roughage, they will have to graze fresh recovery growth, but must not bare this down. A dilemma is caused here when trying to hold ewes on maintenance. Pastures 
have to be saved through to April and May. If the ewes are not held to maintenance in February and March, less feed will be available for flushing. To ration ewes, the dryland area can be used as a runoff, and irrigated pastures grazed on an on-off basis. This saves grazing pastures bare. Weighing ewes will keep a check on the ration.

Flushing begins in the middle of April. Ewes can be in mobs of about 500 and rotationally grazed, moving every 3 days to ensure maximum intake. Ewes flush well on this system.

Tupping is in the second week of May and ewes are kept on a good ration till June, when feed is gradually reduced to a maintenance.

Grass wintering starting at this stage would be difficult. Pasture growth is slow in winter, and winter recovery on many of these low-fertility soils is negligible for about 5 years after border dyking. The late flushing date limits grass wintering.

Stock in July and August can be wintered on a dryland area and maintained on lucerne hay at the rate of $0.8 \mathrm{~kg} \mathrm{DM}$ per ewe daily. In the second week of September, prelamb feeding can start by rotating around irrigated pastures, rested since June, and ewes set-stocked at lambing in October.

Spray-irrigated lucerne can produce at least 400 bales/ha from two cuts, then, for every 10 ha border-dyked and stocked with 200 ewes, 1.1 ha of irrigated lucerne are required to produce adequate winter feed.

\section{Cow Grazing System}

Cows and calves can be break-fed after calving, being fed hay at the rate of 1 bale to 4 cows per day before calving. For the first two-thirds of September, calved cows can be rationed and offered a fifth of their total grazing area with pasture height round $100 \mathrm{~mm}$.

From late September, hay feeding can cease as growth is adequate. Pastures are grazed from $140 \mathrm{~mm}$ to $75 \mathrm{~mm}$. A fourpaddock rotation would allow four days' grazing per paddock, this being extended later in the season when pasture height is greater. The deciding factor for moving cows would be when the pastures are grazed down to $75 \mathrm{~mm}$. Hay has to be fed in September to ensure that pastures grow to a height suitable for grazing cows.

At weaning, calves can be rotationally grazed on leafy pastures about $150 \mathrm{~mm}$ in height. Cows would be strip-grazed behind 
these, on a maintenance ration. By grazing in this manner, feed can be built up for feeding to weaners in the feed deficit period of April. Feed is also available for the continued break-grazing of cows through to the end of July.

From this stage on, cows could be fed lucerne hay on a dryland area. The total hay requirements for cows under this system would be 19 bales per cow. Therefore, for every 10 ha of pasture grazed by cows at $2.7 /$ ha, 1.3 ha of spray-irrigated lucerne will be required, about the same proportion as for ewes. This represents approximately $40 \%$ of the dryland area required for winter feed production, With only two cuts taken, spring and autumn grazing will also be available.

On the question of economics, straw could be substituted for lucerne hay in the early part of August. From then on, better quality feed is required, and a 50:50 ration of straw and lucerne hay could be substituted till September.

\section{LIMITS TO PASTURE PRODUCTION}

Factors which can affect pasture production, and therefore stocking rate, are fertilizers, pasture composition, and pests. Fertilizers have to be applied in economical quantities. For every extra addition of fertilizer, the extra growth must be worth more than the fertilizer cost.

Weed grasses in pastures can seriously affect production and patterns of growth. On the Lower Waitaki Plains, vulpia hairgrass (Vulpia sp.) has reduced the early spring production under irrigation.

Pests, including grass grub (Costelytra zealandica) and porina (Wiseana spp.), can affect annual pasture production. Control measures must be considered if carrying capacities are being threatened.

\section{LIMITS TO ANIMAL PRODUCTION}

Animal performance under high stocking systems can be affected by disease, stock being more susceptible to these when concentrated in large numbers. These diseases can be caused by mineral deficiencies, viruses, bacteria and parasites. Care must be taken to recognize them early and act accordingly.

\section{CONCLUSIONS}

Managing high stocking rate systems requires special skills above those of the average farmer. Feed budgeting must be employed. 
Future feed surpluses and deficits can only be recognized if this budget has been drawn up. Rotations can be changed accordingly. Feed supplies on hand have to be recognized and likely growth anticipated. On the debit side, feed demands have to be known. It is only now that the fairly accurate demands for animals at various physiological states are becoming recognized, and the quantities of different feeds, at various stage's of growth, being applied.

High stocking rates under irrigation are easier to manage because production is guaranteed. Lack of moisture is the major cause of unpredictable pasture growth.

The policies pursued on any farm are related to expected profit. The success achieved will depend on the individual's ability to match demand with supply. The larger the proportion of feed that can be eaten in situ, without wastage, the more efficient will be the total utilization.

Irrigation development is not cheap. The extra feed that is grown will raise the stocking potential by $300 \%$. This must be utilized to pay capital charges and make a profit. Therefore stocking rates on the Lower Waitaki Plains will be high.

\section{ACKNOWLEDGEMENTS}

I am grateful to various farmers and farm advisory officers who have helped give me ideas and assistance with this paper. Also G. Sheath, Field Research Section, Ministry of Agriculture and Fisheries, and K. J. Thompson, Farm Advisory Officer (Animal Husbandry), for data on pasture production and animal requirements.

\section{'REFERENCES}

Frengley, G. A. G., 1973. Proc. N.Z. Grassld A ss., 35: 118-26.

Jagusch, K. T. 1973. Livestock production from pasture. In: Pasture and Pasture Plànts (Ed. R. H. M. Longer), Reed, Wellington, pp. 229-42. 
APPENDIX

FEED PROFILE FOR 55 KG BREEDING EWE ON IRRIGATED PASTURE, NORTH OTAGO.

ANTICIPATED PERFORMANCE 120\% LAMBING, 4-5 KG WOOL

\begin{tabular}{|c|c|c|c|c|c|c|c|}
\hline Month & Feed & $\begin{array}{c}\text { Feed Quality } \\
\text { ME/ } \\
\because ; \quad D M)\end{array}$ & Animal Condition & $\begin{array}{l}\text { Live- } \\
\text { weight } \\
\text { (kg) }\end{array}$ & $\begin{array}{l}\text { Physio- } \\
\text { logical } \\
\text { State }\end{array}$ & $\begin{array}{c}M E \\
\text { Require- } \\
\text { ment } \\
(M J / \text { day })\end{array}$ & $\begin{array}{c}D M \\
\text { Require- } \\
\text { ment } \\
(\mathrm{kg} / \mathrm{day})\end{array}$ \\
\hline Jun. & Grass & 10.0 & Flushing & 55 & M & 9.4 & 0.94 \\
\hline Jul. & Luc. hay & 9.2 & Winter ration & 53 & $0.8 \mathrm{M}$ & 8.0 & 0.87 \\
\hline Aug. & Luc. hay & 12.5 & $\begin{array}{l}\text { Winter ration } \\
\text { Prelambing }\end{array}$ & 55 & $0.8 M$ & $\begin{array}{r}8.0 \\
13.2\end{array}$ & 0.87 \\
\hline $\begin{array}{l}\text { Sep. } \\
\text { Oct. }\end{array}$ & $\begin{array}{l}\text { Grass } \\
\text { Snring growth }\end{array}$ & $\begin{array}{l}12.5 \\
12.5\end{array}$ & Lambing & 52 & $3.0 \mathrm{M}$ & 26.4 & 2.1 \\
\hline Nov. & Spring growth & 10.9 & Ewe and lamb & 53 & $2.5 \mathrm{M}$ & 23.0 & 2.1 \\
\hline Dec. & Summer pasture & 9.5 & Ewe and lamb & 60 & $2.0 \mathrm{M}$ & 20.0 & 2.1 \\
\hline Jan. & Summer pasture & 7.5 & Weaning, maintenance & 55 & M & 10.0 & 1.3 \\
\hline Feb. & Late summer & 7.5 & Weaning, maintenance & 55 & M & 10.0 & 1.3 \\
\hline Mar. & $\underset{\substack{\text { Summer } \\
\text { S P }}}{\text { saved }}$ & 10.9 & Weaning, maintenance & 55 & M & 9.2 & 0.85 \\
\hline May & A.S.P. & 10.5 & Flushing & $5 \beta$ & $1.5 \mathrm{M}$ & $144: 9$ & $1: 4$ \\
\hline \multicolumn{8}{|c|}{ Lambs Daily Livew ight Gain $200 \mathrm{~g} /$ day } \\
\hline Jan. & Long leafy pasture & 10.9 & Growing & $20^{\circ}$ & & 11.3 & 1.04 \\
\hline Feb. & Long leafy pasture & 10.9 & Growing & 26 & & 12.4 & 1.14 \\
\hline
\end{tabular}

